\title{
9. The information systems discipline in Victoria
}

\author{
Carol E. Pollard \\ Appalachian State University \\ Boone, North Carolina, USA \\ Elsie S. K. Chan \\ Australian Catholic University \\ Victoria, Australia
}

\begin{abstract}
This chapter describes the current state of the Information Systems (IS) discipline within the state of Victoria, Australia. It reports on the ways in which Victorian universities are addressing the challenges associated with reducing local and international student demand, and hence enrolments, at a time when IS in particular and information and communications technology (ICT) in general are seen by the business sector as necessary components contributing to organisational success. Transcripts of interviews with 14 academics at nine universities throughout Victoria are analysed to give a current profile of IS programs and identify the trends in their development over time. First, a profile of the state of Victoria, its education system and its ICT industry is provided to place this work in context. Next, the interview sample is described and a number of relevant topics of interest are identified and discussed, comparing and contrasting the various programs. Third, a summary of the findings is provided in light of the framework used to guide the larger study of the Australian IS programs, which includes an assessment of the impact of mechanisms of control and the core body of knowledge on research and teaching methods and standards, key research and teaching IS topics and laws, and rules and guidelines used within the IS programs. Finally, the relationship between the impact of local contingencies and the degree of professionalism is examined.
\end{abstract}

\section{Introduction}

Information systems is a fascinating and pervasive discipline that has struggled in the past three decades to establish itself as a distinct scientific discipline. This has proved somewhat difficult and elusive, possibly due in part to the fact that 
IS is not confined only to business activities but profoundly affects our social activities (see, for example, Buckingham et al. 1987; DeSouza et al. 2006; Lee 2001; Lo 1989; Fielden 1990; Ang 1992; Ang and Lo 1991; Avison 1993; ACM et al. 1997; Clarke 1999; Tatnall 1999).

[T] he information systems field examines more than just the technological system, or just the social system, or even the two side by side; in addition, it investigates the phenomena that emerge when the two interact. (Lee 2001:iii-vii)

In a recent communication to an international Listserv from Sid Huff, Chair of Information Systems at the University of Auckland, he referenced a recent Information Technology (IT) Governance Institute report that noted the view that IS was an important and integral component of the business value of organisations.

Given this, it follows that as the importance of IS has grown in business and government and has become more pervasive in our social lives, the educational and research programs that support IS have needed to evolve and stay abreast of business and social needs locally and globally and remain an attractive option for students. Unfortunately, in the past several years there has been an unprecedented decline in student enrolment in IS programs world-wide because of a perceived reduction in IS job opportunities. More recently, some Australian university administrations have been responding by drastically reducing the number of IS academics on staff.

This chapter reports on a study within a larger study of IS in Australia that investigates the evolution of IS teaching and research programs throughout Australia. The focus of this chapter is on the IS discipline within the state of Victoria and reports on how universities have taken on the teaching and research challenges associated with the dichotomy of reduced enrolments and the increasing importance of IS/IT to business, and explores the extent to which they have succeeded.

First, a profile of the state of Victoria, its education system and its ICT industry is provided to put the work in context. Next, the interview sample is described and a number of relevant topics of interest are discussed, comparing and contrasting the various programs. Finally, a summary of the findings is provided in light of the framework used to guide all of the state studies of the Australian IS discipline included in this book. 


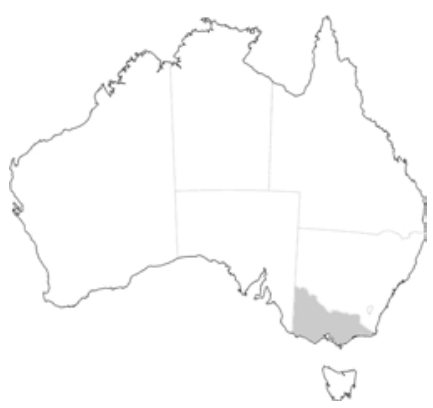

Figure 9.1 Location of Victoria within Australia

\section{Purpose of the Victorian study}

The state of Victoria is located in the south-eastern corner of the mainland of Australia. It is the smallest mainland state in area-representing only 3 per cent of the Australian land mass - but it is the most densely populated and urbanised state. Victoria began as a farming community in the 1800s. The discovery of gold at Anderson's Creek near Melbourne, in 1851, transformed it into a leading industrial and commercial centre and, in 1901, Victoria was designated officially as an Australian state. In September 2005, Victoria's population reached an estimated 5087300 - making it the second-most populous Australian state, after New South Wales (Wikipedia, The Free Encyclopedia 2007).

Victoria is home to a vibrant and sophisticated ICT industry, which boasts a strong component of locally grown companies. Australian-owned firms account for approximately 69 per cent of the industry in Victoria. It is a centre for research and development, which is leading the Australian (and often global) research and development programs across a broad range of industry sectors.

In 2001-02, Victoria's globally focused ICT industry had a turnover of A $\$ 19.8$ billion (US\$15.3 billion) and a skilled and creative workforce of 60000 . With export revenue of $\mathrm{A} \$ 615$ million (US\$476.4 million) and research and development expenditure of A $\$ 303$ million (US\$235 million), the ICT industry is at the heart of the modern Victorian economy. Although Victoria accounts for less than 25 per cent of Australia's population, it is home to 31 per cent of all Australian ICT jobs. These make up 48 per cent of all jobs in hardware manufacturing, 41 per cent of jobs in software engineering and 35 per cent of all ICT consulting jobs (Government of Victoria 2005). For example, leading Israeli IT services and solutions provider Ness Technologies Inc opened its Australia-New Zealand headquarters in Melbourne in April 2006, creating up to 50 new jobs (Government of Victoria 2006).

High Internet usage rates and world-class infrastructure make Victoria a test bed for e-commerce companies and, as a result, Victoria has emerged as Australia's leader in business-to-business and business-to-consumer e-commerce. Recently, 
it was reported that Melbourne in particular had a critical mass of creativity and skills to develop a competitive ICT hotspot (Newcomersnetwork.com 2006). These statistics provide a natural conduit for a discussion of the evolution of the many strong ICT programs that exist within Victorian universities.

\section{The research method}

The Victorian study utilises the case-study method. Walsham (1993, 1995) recommends case studies for interpretivist research, although this is by no means the only way in which case studies can be used, as clarified by Yin (2003). Hence a qualitative, interpretivist approach was chosen to conduct the research on which this chapter is based. Within and between this, case analysis was performed to offer a rich description and comparison of IS programs at the nine universities represented, as indicated in Table 9.1.

Face-to-face interviews were conducted with 14 senior academics in 2005 . The number of interviews conducted at each university ranged from one to three, depending on the availability of participants, and included one key person from each university as the primary source of data. The semi-structured face-to-face interviews were based primarily on the standardised interview protocol developed for use in the larger IS-in-Australia study. In the interest of obtaining rich data, however, and within the constraints of collecting equivalent data systematically from each participant, interviewees were not discouraged from varying the order of the interview format during the interview.

At the outset of each interview, the researcher opened the session with a set of standard introductory remarks designed to: 1) indicate the importance and purpose of the interview; 2) give assurance of anonymity and confidentiality to the participant; and 3) establish rapport. Each interview began with elicitation of demographic information (name, title, department) and then sought information on the following topics of interest:

- the relative size and administrative placement of the IS presence at their university

- the extent to which IS at the university was impacted on by local contingencies

- the extent to which IS was identified as a separate field at their university

- distinctive features of the IS curriculum at their university

- distinctive features of IS research at their university

- the key people who has had an impact on IS in universities in Victoria.

Available documentation and archival material was also collected and analysed to provide some triangulation of data (Denzin and Lincoln 1998). 


\section{Theoretical framework guiding the study}

Two frameworks were used to guide this study and evaluate its findings. The first was Whitley's theory of scientific change (1984b), which proposed that three conditions were needed for the establishment of a distinct scientific field. These three conditions are:

1. scientific reputations to become socially prestigious and to 'control critical rewards'

2. establishing standards of research competence and skills

3. a unique symbol system to allow exclusion of outsiders and unambiguous communication between initiates within the field.

Second, an updated framework proposed by Ridley (2006) was applied to the data collected. This more recent framework extends the Whitley set of conditions to include two additional conditions necessary to establish a distinct scientific field. Ridley's two additional conditions are:

1. laws, rules and evidenced guidelines

2. research and teaching key topics.

Ridley (2006) categorises the various criteria into two main components: mechanisms of control and a core body of knowledge (research and teaching methods and standards, the existence of a unique symbol set, key research and teaching topics and laws, rules and evidenced guidelines). She also proposes that it is important to add two other components - that is, the impact of local contingencies and the degree of professionalism - to evaluate the variation in IS programs in Australian universities and to track progress and compare programs in a given state.

More detail of the framework and its derivation are provided in Chapter 3 of this volume.

\section{The universities in this study}

Currently, Victoria has nine public universities, as shown in Table 9.1. Data were gathered from all nine universities. The oldest, the University of Melbourne, enrolled its first student in 1855. The largest, Monash University, has an enrolment of nearly 56000 students - more than any other Australian university in 2004. Two of Victoria's universities - the University of Melbourne and Monash University - are members of the Group of Eight (Go8), an organisation that represents Australia's leading universities (www.go8.edu.au/). The total number of students enrolled in Victorian universities was 241755 in 2004-an increase of 2 per cent from 2003. The largest number of enrolments was recorded in the fields of business, administration and economics, with nearly one-third of all students, followed by arts, humanities and social science, with 20 per cent of 
enrolments. ${ }^{1}$ International students in Victoria make up 30 per cent of all enrolments.

\section{Relative size of the IS presence in Victorian universities}

The number of IS tertiary students in Victoria is approximately 7000. A comparison of the size of the IS presence ranges from 76 students at the Australian Catholic University (ACU; Melbourne campus) to approximately 1000 at the Universities of Ballarat and Monash, as shown in Table 9.1. Full-time IS academic staff number from three at the ACU (nationally) to 92 at the Royal Melbourne Institute of Technology (RMIT). It was noted, however, by those interviewed at Monash that their faculty size had been culled significantly since 2004 due to falling student numbers in the previous few years. Also in 2006, the School of Information Systems at Victoria University reduced its IS staff by nearly 54 per cent (from 26 to 14) as a first measure in staff reduction.

Table 9.1 IS presence in universities in Victoria

\begin{tabular}{l|c|c}
\hline University & No. of full-time IS academic staff & No. of IS students \\
\hline ACU (national) & 3 & 76 \\
\hline Deakin & 68 & 3305 \\
\hline La Trobe & 16 & 252 \\
\hline Monash & 150 & 1000 \\
\hline RMIT & 92 & 622 \\
\hline Swinburne & 52 & 500 \\
\hline Melbourne & 45 & 400 \\
\hline University of Ballarat & 54 & 1010 \\
\hline Victoria University & 61 & 800 \\
\hline
\end{tabular}

\section{The administrative placement of IS in Victorian universities}

While all nine universities in Victoria represented in the study offer IS programs, the location of the programs within the university structure differs by institution. Table 9.2 shows that IS programs in universities in Victoria can be categorised between business and science/technical/engineering faculties. Six departments are located within faculties of science/technical/engineering, whereas Deakin, RMIT and Victoria University offer IT programs through the business and the science/technical/engineering faculties.

The home faculties in which IS in Victorian universities was situated indicated a diverse mix. The two main faculties, shown in Table 9.2, are business and science; however, IS is also situated in an interesting mix of arts, law, engineering, communication and health science faculties. The demarcation between a science and/or a business focus in IS departments is quite clear. This

\footnotetext{
1 Australian Bureau of Statistics, Department of Education and Training (Victoria), Department of Education, Science and Training (Commonwealth 2005) and National Centre for Vocational Education Research cited in Wikipedia, The Free Encyclopedia (2007).
} 
diversity of home faculties seems to indicate that, on the whole, IS has not matured in Victoria as a stand-alone discipline.

Table 9.2 Placement of IS in Victorian universities

\begin{tabular}{l|l|l|l}
\hline University & Department, school or group & Home faculty & Demarcation \\
\hline ACU (national) & Business and Informatics & Arts and Sciences & Science \\
\hline Deakin & $\begin{array}{l}\text { Information Systems } \\
\text { Information Technology }\end{array}$ & $\begin{array}{l}\text { Business and Law } \\
\text { Science and Technology }\end{array}$ & $\begin{array}{l}\text { Business } \\
\text { Science }\end{array}$ \\
\hline La Trobe & $\begin{array}{l}\text { Computer Science and } \\
\text { Computer Engineering }\end{array}$ & $\begin{array}{l}\text { Science, Technology and } \\
\text { Engineering }\end{array}$ & Science \\
\hline Monash & $\begin{array}{l}\text { Berwick School, Caulfield } \\
\text { School, Clayton School, } \\
\text { Gippsland School }\end{array}$ & Information Technology & IT \\
\hline RMIT & $\begin{array}{l}\text { Business Information } \\
\text { Technology } \\
\text { Computer Science and } \\
\text { Information Technology }\end{array}$ & $\begin{array}{l}\text { Business } \\
\text { Science, Engineering and } \\
\text { Technology }\end{array}$ & Business \\
Science \\
\hline Swinburne & $\begin{array}{l}\text { Astrophysics and } \\
\text { Supercomputing } \\
\text { Computer Science and } \\
\text { Software Engineering } \\
\text { Information Systems } \\
\text { Telecommunications }\end{array}$ & $\begin{array}{l}\text { Information and } \\
\text { Communication Technologies }\end{array}$ & IT \\
\hline Melbourne & $\begin{array}{l}\text { Information Systems } \\
\text { Software Engineering }\end{array}$ & $\begin{array}{l}\text { Science } \\
\text { Engineering }\end{array}$ & \\
\hline University of Ballarat & $\begin{array}{l}\text { Information Technology and } \\
\text { Mathematical Sciences }\end{array}$ & $\begin{array}{l}\text { Information Technology and } \\
\text { Mathematical Sciences }\end{array}$ & IT \\
\hline Victoria University & $\begin{array}{l}\text { Information Systems } \\
\text { Computer Science and } \\
\text { Mathematics }\end{array}$ & $\begin{array}{l}\text { Business and Law } \\
\text { Health, Engineering and } \\
\text { Science }\end{array}$ & $\begin{array}{l}\text { Business } \\
\text { Science }\end{array}$ \\
\hline
\end{tabular}

Despite the placement of six of the nine IS departments within a non-IS home faculty, data revealed a move in an overwhelming majority of universities in Victoria to recognise IS as a separate entity. Table 9.3 shows that only three of the nine Victorian universities represented have not attained a separate identity for IS. In universities where there was a separate IS identity, this was expressed as:

- a clear demarcation between IS subjects and others in the faculty (RMIT, Victoria University)

- a strong reputation in industry (Swinburne)

- IS had long had a strong separate identity (Monash).

A specific example might serve to explain this better. For many years in the 1970s and 1980s, Caulfield and then Chisholm Institute of Technology pioneered IS education in Victoria. An early activity was the Commonwealth government's Programmer-in-Training (PIT) scheme. Some people also raised the issue of 'competing' with business, IT and computer science departments in connection with the existence of a separate identity.

Overall, the existence of a separate identity for IS was viewed positively, although at Melbourne it was indicated that while IS had a separate identity as a 
department, 'not many people know about our department'. Of the three universities (ACU National, University of Ballarat and La Trobe) that do not afford IS a separate identity, La Trobe has experienced some problems with this status, including the lack of representation of IS journals and conferences in a recent journal and conference ranking exercise undertaken to improve the department's (Computer Science and Computer Engineering) research profile. At the University of Ballarat, IS does not have separate administrative status and IS lecturers teach into other areas of the School of Information Technology and Mathematical Science. This is also true for ACU National, as one of the three IS lecturers teaches the business units and IS does not have separate administrative status.

Despite the generally positive perception of having a separate identity, senior academics in Victoria were relatively evenly divided between 'same' and 'less' in their views on status as shown in Table 9.3. Only one senior academic at Monash felt that IS academics were viewed more highly than their colleagues in other departments. At the four universities in Victoria where it was perceived that IS academics saw themselves as having a lesser status than their colleagues a number of reasons were given.

- In some cases it appeared to be due to the relatively new and evolving nature of IS departments in Australia (Melbourne, RMIT, Victoria University).

- A respondent representing Swinburne felt that the perception of the IS faculty was that they were 'less prominent in research than their colleagues'.

- At those universities where the perception was that there was no difference between the status of IS academics and their colleagues no elaboration for this perception was forthcoming.

Interestingly, Table 9.3 also shows that status and separate identity are not necessarily correlated. For example, academics at the University of Ballarat considered their status 'no more or less' and those at La Trobe were said to have mixed perceptions of status. In contrast, at those universities that had a separate identity, many viewed themselves as having less status for the reasons described above.

Table 9.3 IS identity and status in universities in Victoria

\begin{tabular}{l|l|l}
\hline University & Separate identity & Status \\
\hline ACU National & No & Same \\
\hline Deakin & Yes & Same \\
\hline La Trobe & No & Same/less \\
\hline Monash & Yes & Same/higher \\
\hline RMIT & Yes & Less \\
\hline Swinburne & Yes & Less \\
\hline Melbourne & Yes & Less \\
\hline University of Ballarat & No & Same \\
\hline Victoria University & Yes & Less \\
\hline
\end{tabular}




\section{Distinctive features of the IS curriculum}

Universities in Victoria offer a wide range of undergraduate and postgraduate IS courses and programs. Table 9.4 summarises the programs offered at the various institutions.

While the majority of the nine institutions represented offer the standard suite of BIS and BIS (Hons), Graduate Certificate, Graduate Diploma and Masters-level programs, Table 9.4 shows a wide range of innovative IS programs. Within Victoria, all universities offered PhD-level IS programs, although not all universities currently had PhD students enrolled (University of Ballarat) or they reported very small enrolments (ACU National, La Trobe and Swinburne).

\section{Table 9.4 Diversity of IS programs offered}

\begin{tabular}{|c|c|c|}
\hline University & Undergraduate courses/program & Postgraduate courses/program \\
\hline ACU National & $\begin{array}{l}\text { BIS } \\
\text { BIS (Hons) } \\
\text { Bachelor of Business/BIS }\end{array}$ & PhD \\
\hline Deakin & $\begin{array}{l}\text { BIT (IT Security) } \\
\text { BIS/BIT } \\
\text { BIS } \\
\text { BIS (Hons) } \\
\text { BEng/BIT } \\
\text { BIT (Multimedia Technology) } \\
\text { BIT (CS and Software Development) } \\
\text { BIT (Games Design and Development) } \\
\text { BIT (Web and Mobile Technologies) }\end{array}$ & $\begin{array}{l}\text { MArts (Professional Communication)/MIT } \\
\text { MIT } \\
\text { MIT (Professional) } \\
\text { MIT/MCom } \\
\text { MIT/MIS } \\
\text { MAcct'g IS } \\
\text { MCom/MIS } \\
\text { PhD }\end{array}$ \\
\hline La Trobe & $\begin{array}{l}\text { BIT (Computer Networks) } \\
\text { BIT/IS } \\
\text { BIT (Software Development) } \\
\text { BIS/BBus }\end{array}$ & $\begin{array}{l}\text { MIT (Computer Networks) } \\
\text { MIT (Intelligent Systems and Internet } \\
\text { Computing) } \\
\text { PhD }\end{array}$ \\
\hline Monash & \begin{tabular}{|l|}
$\mathrm{BIS}$ \\
$\mathrm{BIT} / \mathrm{BIS}$ \\
$\mathrm{BArts} / \mathrm{BIM}$ and IS \\
BCom/BIS
\end{tabular} & $\begin{array}{l}\text { MApplied IT } \\
\text { MBA/MIM and IS } \\
\text { MIM and IS } \\
\text { MIM and IS (Professional) } \\
\text { MIS } \\
\text { MIT } \\
\text { MIT (Minor thesis) } \\
\text { PhD }\end{array}$ \\
\hline RMIT & $\begin{array}{l}\text { BBus (BusIS) } \\
\text { BAppSc (Computing and Internet } \\
\text { Technology) } \\
\text { BAppSc (IT) } \\
\text { BAppSc (Honours-Computing and } \\
\text { Internet Technology) }\end{array}$ & $\begin{array}{l}\text { MBus (BusIT) } \\
\text { MAppSc (Information Security) } \\
\text { MAppSc (IS) } \\
\text { MAppSc (IT) } \\
\text { MEng (IT) } \\
\text { MTech (IT) } \\
\text { MTech (Internet and Web Computing) } \\
\text { PhD }\end{array}$ \\
\hline
\end{tabular}


Table 9.4 Diversity of IS programs offered

\begin{tabular}{l|l|l}
\hline University & Undergraduate courses/program & Postgraduate courses/program \\
\hline Swinburne & BIT (Honours) & MIS Mgmt/MAcct'g \\
& BSc (IT) & MIS Mgmt \\
& BIS (Honours) & MIS Mgmt/MBA \\
& BIT & MTech (IT) \\
& BBus (IS)/BBus & MIT \\
& BBusIS & PhD \\
\hline Melbourne & BIS & MBus/IT \\
& BIS (Honours) & MIS \\
& & MIT \\
& & MIT in Education \\
\hline University of Ballarat & BIS & PhD \\
& BIT & MBusIS \\
& BIT (Professional Practice) & MIS \\
& & MIT \\
& & MIT Studies \\
& & MIT Studies/MBA \\
& & MICT \\
\hline Victoria University & BBus (Acct/IS) & PhD \\
\hline & BBus (IS) & Master of Business in Information \\
& BBus (Tourism Management/IS) & Systems \\
& BA/BBus (Information Systems) & Master of Business in Information \\
& BSus (IS) (Honours) & Systems and Enterprise Resource Planning \\
\hline
\end{tabular}

In addition to the traditional Bachelor of Information Systems or Information Technology, Bachelor of Business Information Systems and the Masters of Information Systems, a few institutions offer cross-disciplinary courses, such as the Bachelor of Computing with Applied Science and BComp with Visual Arts at La Trobe and the Bachelor of Computing/Information Systems offered at Swinburne. Victoria University offers joint degrees with arts and science and engineering faculties and a Masters in Enterprise Resource Planning and Marketing/E-Commerce. The ACU National offers double degrees in IS and business majoring in accounting, marketing and human resource management. It was observed that in 2002 students tended to study a single degree, Bachelor of Information Systems. Starting from 2004, students preferred to study a double degree. The reason for this change could be due to the perceptions of graduates, who believe those with double degrees will find jobs more easily than those with a single degree. Many of the universities have a large population of international students, the majority of whom are from Asia, with only a small representation from Europe. The offshore IS programs that are offered overseas include campuses in Hong Kong, Thailand, Singapore, China and Malaysia. Generally speaking, the courses taught in IS programs are less technical than would be found in a department of computer science or IT. 
The distinctive themes taught within many of these programs varied considerably and included decision analysis and information management (Monash), global IS (University of Ballarat), electronic commerce (Deakin), enterprise resource planning (ERP), security and privacy (Victoria), design and support of business processes (Swinburne), educational theory and practice (La Trobe), ERP (Victoria University) and security, decision support, usability and interface design, business intelligence and ERP (RMIT).

It is also interesting to observe that universities offer many IS/IT-related Masters programs now compared with a decade ago. As mentioned in Keen (1996:129-32), there were only three universities offering IS/IT-related Masters programs by course-work. They were Master of Information Systems at Monash, Master of Business (IT) at RMIT and Master of Business in Computing at Victoria University of Technology (now renamed Victoria University).

The current diversity of IS curricula and degrees offered at all levels in Victorian universities is inconsistent with the Ridley framework requirement that a maturing discipline must have a readily identifiable core body of knowledge.

\section{Distinctive features of IS research}

Turning from the teaching profile and diversity of programs to that of research, an interesting and similar picture emerges. Table 9.5 demonstrates the diversity of research streams under way in universities in Victoria and recognises two successful formal research centres. Those universities that have active PhD programs have been successful in varying degrees in attracting and maintaining PhD students to support, in part, their research programs.

\section{Table 9.5 Research streams in universities in Victoria}

\begin{tabular}{l|l|l|l}
\hline University & Areas of research & Formal research groups & No. of PhD students \\
\hline ACU National & $\begin{array}{l}\text { IS education } \\
\text { E-commerce education }\end{array}$ & & 1 \\
\hline Deakin & $\begin{array}{l}\text { Requirement engineering } \\
\text { IT security } \\
\text { Knowledge management } \\
\text { Supply-chain management } \\
\text { Software engineering } \\
\text { E-commerce }\end{array}$ & $\begin{array}{l}\text { Supply-Chain Management } \\
\text { (SCM) and } \\
\text { Business-to-Business (B2B) } \\
\text { e-Commerce }\end{array}$ & 20 \\
\hline La Trobe & $\begin{array}{l}\text { Computational intelligence } \\
\text { IS education } \\
\text { Equity issues of women in IT } \\
\text { IT adoption and impact }\end{array}$ & & \\
\hline
\end{tabular}


Table 9.5 Research streams in universities in Victoria

\begin{tabular}{|c|c|c|c|}
\hline University & Areas of research & Formal research groups & No. of PhD students \\
\hline Monash & $\begin{array}{l}\text { Knowledge management } \\
\text { Systems development } \\
\text { Decision support systems } \\
\text { Information management } \\
\text { IT management } \\
\text { E-business } \\
\text { Conceptual modelling }\end{array}$ & $\begin{array}{l}\text { Centre for Decision Support } \\
\text { and Business Intelligence } \\
\text { Research }\end{array}$ & 60 \\
\hline RMIT & $\begin{array}{l}\text { Strategic IS } \\
\text { E-learning } \\
\text { E-commerce }\end{array}$ & $\begin{array}{l}\text { Knowledge management } \\
\text { E-business }\end{array}$ & 30 \\
\hline Swinburne & $\begin{array}{l}\text { IS governance } \\
\text { Process modelling } \\
\text { IS project management } \\
\text { Health informatics }\end{array}$ & $\begin{array}{l}\text { Centre for Information } \\
\text { Technology Research }\end{array}$ & 1 \\
\hline Melbourne & $\begin{array}{l}\text { E-commerce } \\
\text { Technology adoption } \\
\text { Usability design } \\
\text { Security }\end{array}$ & Knowledge discovery & 40 \\
\hline University of Ballarat & \begin{tabular}{|l|} 
IT education \\
Data mining and informatics \\
Mathematics and statistical \\
analysis \\
Distributed simulation
\end{tabular} & $\begin{array}{l}\text { Centre for Informatics and } \\
\text { Optimisation (CIAO) }\end{array}$ & 0 \\
\hline Victoria University & $\begin{array}{l}\text { Semantic webs } \\
\text { Business process modelling } \\
\text { Negotiation support } \\
\text { Legal systems in IS } \\
\text { Ethics, privacy and } \\
\text { censorship } \\
\text { Portals for medical and } \\
\text { aged-care support } \\
\text { ERP }\end{array}$ & $\begin{array}{l}\text { Electronic commerce } \\
\text { research }\end{array}$ & 16 \\
\hline
\end{tabular}

Overall, IS research output in universities in Victoria was seen as being lower than in other departments. It should be noted, however, that for the most part IS research output appears to have been increasing in the past three to five years. Efforts are under way to bolster research output. Comments indicative of this include one at Monash to the effect that '[a]ll IS academics will be expected to be "research active" by 2008' and, one from the University of Ballarat, where it is a current requirement that 'all academics in the school are expected to undertake research'.

The mode of IS research in universities in Victoria is predominantly interpretive. Only the University of Ballarat reported using 'multi-method, with an emphasis on quantitative techniques'.

Although research is considered a high priority at almost all universities in Victoria, available funding appears to have a negative correlation with the avowed importance of research. Perceptions of 'very little funding', 'dwindling 
funding' and 'having trouble attracting ARC [Australian Research Council] and other external funding' were evident in the data. Where funding has been obtained, it is primarily in the form of competitive grants from internal university sources or associated with established research centres, with some funding forthcoming from industry. Relatively few IS departments have been successful in securing external grants from agencies such as the ARC, although there appears to be a trend towards encouraging external grants rather than relying on internal funding, which in almost all cases was seen to be increasingly difficult to secure.

Respondents stressed that rewards, when available, were being awarded increasingly for research that resulted in journal publications rather than conference chapters.

\section{Key people who have had an impact on IS in universities in Victoria}

A number of key individuals were recognised for their contributions to IS in Victorian universities. Predominantly, these individuals were long-standing academic leaders.

Examples included Tony Adams at RMIT, who was named as the champion for the establishment and direction of the IS department, along with Marianne Broadbent, head of the former Information Management School in arts, who worked with Professor Adams to establish the RMIT IS research and course-work frameworks. Robert Johnson was identified as an influential force at Melbourne University, as was Gerald Murphy at Swinburne and Angela Scollary for her tireless work to establish the IS school at Victoria University. The respondent from the University of Ballarat recognised Professor Sid Morris, their head of school, as one who 'has had a huge amount to do with the success we are having', and acknowledged the important contributions of Professor Wayne Robinson, University of Ballarat's Deputy Vice-Chancellor (Academic and Research), together with that of Professor Alex Rubinov, Director of the CIAO.

A long list of influential individuals was forthcoming from respondents at Monash. These included Gerry Maynard for his leadership in establishing the IS department; Jack Greig, current head of IS and the person responsible for the introduction of systems analysis units; Phil Steele, David Arnott, Graeme Shanks, Frada Burstein, Julie Fisher, Ron Weber and Ian Martin, an academic involved in industry-based learning at the Clayton campus. Less frequently mentioned, but no less important, were those non-academics who were seen to have influenced course design and skill requirements, such as the representatives at Bendigo Bank who were supportive and influential at La Trobe.

Vignettes of two of the many influential figures in the IS discipline in Victoria are presented next. 


\section{Vignette 1-Graeme Shanks}

Graeme Shanks has had a major impact on IS in Victoria during his 25 years as an academic. Currently, he is a Professorial Fellow in the Department of Information Systems at the University of Melbourne. Until recently, he was Associate Dean of Research and Professor in the School of Business Systems in the Faculty of Information Technology at Monash University. Before becoming an academic, Shanks worked for a number of years as programmer, programmer-analyst and project leader in several large organisations. Shanks has a number of research and teaching interests, including conceptual modelling, data quality, identity management and the implementation and impact of enterprise systems and inter-organisational systems.

Shanks began his academic career in 1982 at the Chisholm Institute of Technology in Melbourne. He was course leader for graduate programs in IT and helped to develop the first Australian course-work degree in IT in the mid-1980s. Many years later, he led the restructuring of the Master of Information Systems program at the University of Melbourne. Over many years, Shanks has developed subjects in the areas of data management, systems analysis, conceptual modelling, enterprise systems and data warehousing. He has published several papers on curriculum development in these areas. Shanks has successfully supervised eight PhD students to completion.

Shanks has been involved actively with the Australian Conference on Information Systems (ACIS), having presented a paper at the first ACIS in 1990; he was Program Chair of ACIS1994 at Monash University, and presented many papers and panel sessions in the years since. At the 1994 conference, together with others including David Arnott, Graham Pervan, Bernie Glasson and Rudi Hirschheim, he helped to devise the 'evolving charter' for ACIS, which defines the governance and operation of the conference series. He was executive officer of ACIS for several years, helping to ensure the successful operation of the ACIS series. Shanks has been an active member of the Australian Computer Society (ACS) for many years and was elected a Fellow in 1999. He also served on the committee of the Data Management Association. Shanks has been a member of the Australian Council of Professors and Heads of Information Systems (ACPHIS) for many years.

Shanks completed a PhD in IS in 1997 and has since focused strongly on research. $\mathrm{He}$ is a member of several editorial boards, including Asia Pacific Management Review (Regional Editor), Journal of Knowledge Management Theory and Practice, Data Warehousing Journal, International Journal of Data Warehousing and Mining, Journal of Database Management and the New Zealand Journal of Applied Computing and Information Technology. He has published the outcomes of his research in more than 100 refereed journal and conference papers in outlets including Information Systems Journal, Journal of Information Technology, Journal 
of Strategic Information Systems, Communications of the ACM and the International Conference on Information Systems (ICIS).

During his career, Shanks has received more than $\$ 1$ million in research funding from the ARC, including Discovery grants and industry linkage grants. He was a member of the ARC College of Experts from 2004 to 2005, representing the IS community. He has presented seminars on ARC grant schemes throughout Australia and at the annual ACPHIS workshops.

\section{Vignette 2-Gerald Murphy}

Gerald Murphy is one of the founding fathers of Australia's IT education sector, having completed a commerce degree at the University of Melbourne in 1960, when computers received only a passing mention in one subject.

After nine years in the IT industry, Murphy moved to Swinburne University of Technology (now Swinburne University), where the challenge had become producing graduates who were not too IT focused. There he was instrumental in establishing the Bachelor of Information Technology (BIT) in 1998. The BIT was part of a national pilot program initiated by the Business Council of Australia and currently generates approximately $\$ 1$ million in scholarships annually.

During his career at Swinburne, Murphy made a distinguished contribution to ICT through his pioneering work in cooperative education in IT, introducing other innovative courses, and gaining recognition for IT management as an independent course. Murphy's important contributions were recognised in 1997, when he was awarded the World Association's MacLaren Prize for his contribution internationally to work-integrated learning.

As a result of his further contributions to the IS field, Murphy was installed as a Fellow of the ACS in 2005.

Since retiring from Swinburne University, Murphy has continued his work in a number of innovative industry programs. He is currently the Certification Program Manager of the ACS and Chair of the Australian Cooperative Education Society. In this role, Murphy writes regularly for Computerworld and other industry publications to further promote the IT profession.

In his role as Chair of the Australian Cooperative Education Society, and his former role as manager of an employer-sponsored degree course at Swinburne University, he has developed an excellent understanding of how to integrate subject content with work experience and how to encourage employer support for those undertaking such study.

\section{The status of IS as a distinct discipline in Victoria}

In the short term, relating the Victorian data to the underlying framework that guides the IS-in-Australia study as proposed by Whitley (1984b) and refined by 
Ridley (2006), it would appear that the Victorian data do not support IS as a distinct scientific discipline under the conditions for acceptance as an academic discipline. Each of the framework's criteria will be addressed separately in light of the Victorian data to demonstrate the conclusions reached.

The first of Whitley's three conditions that must be met in order for an area of study to be considered a 'distinct scientific field' is a social process that results in scientific reputations becoming socially prestigious and controlling critical rewards. Mingers and Stowell (1997) suggest this can be evidenced through publications and success in attracting research funding. Clearly, Victorian researchers view themselves as being somewhat less respected than their counterparts in other disciplines, with only one respondent feeling that IS researchers were of higher status than those in other departments. On the other hand, documentary evidence shows that a number of senior IS academics in Victoria have attained status as full professors and are recognised as being as qualified as their peers in other more mature disciplines. The deficiency in meeting this criterion is perhaps more telling in regard to 'attracting research funding', where the data demonstrate clearly that external funding support for IS research continues to be elusive and IS researchers appear to be losing ground as they struggle with dwindling internal funding.

The second of Whitley's criteria is the need to establish standards of research competence and skills. Here, the Victorian data add to the long-standing discussion about whether IS is a discipline (Dickson et al. 1982; Benbasat and Weber 1996; Boudreau et al. 2001) and the current perception that IS continues to align itself more closely with a 'fragmented adhocracy', as suggested by Checkland and Holwell (1998) and Kanungo (2004), than a distinct discipline. For example, while there were pockets of successful grant applications and a limited number of research centres throughout the state, the data revealed an overall lack of success in attracting research funding. This could be construed as a negative reflection on research competence and skills that appeared to be limited to interpretivism and lacking the application of the more diverse, blended approach usually evident in more mature disciplines.

The third and final Whitley criterion is one that requires the existence of a unique symbol system to allow exclusion of outsiders and unambiguous communication between initiates within the field. There are a few IS departments that have achieved autonomy (Monash, Swinburne, University of Ballarat), but for the most part the IS programs are situated within business, arts or science faculties. Similarly, only two-thirds of Victorian IS programs are recognised as separate entities and the diversity of research topics under scrutiny would clearly demonstrate a heavy reliance on reference disciplines with little or no discussion of the use of an IS theory. This would suggest that this criterion has not been met. 
Applying Ridley's (2006) two additional criteria - theory or laws, rules and evidenced guidelines and research and teaching key topics-led to mixed conclusions. As to theory, there appears to be a strong focus on interpretivist research methods, which could lead to the conclusion that in IS programs in Victoria there is an agreed set of laws, rules and evidenced guidelines. This is not the case with respect to teaching. The distinctive themes taught within many of the IS programs vary considerably, and it is difficult to see any key teaching topics across programs and institutions in Victoria. Similarly, little evidence points to a coherent set of key research topics. Table 9.5 lists no less than 33 different areas of research across the nine Victorian universities. This indicates that even within a single program there is no homogeneous set of key research topics, with the exception of the ACU National, where its research focuses almost exclusively on IS/e-commerce education.

Finally, we assess the data with respect to the relationships between the degree of professionalism and impacts of local contingencies. Whitley (1984a, 1984b) suggests that to be professional a discipline will not be highly influenced by local contingencies. From the data collected in Victoria, it would appear that while universities in Victoria are currently seeking increased collaboration with the local community and industry as part of their strategic vision - as in the strong industry-based learning degree programs at Swinburne and Monash Universities, established about 1990 as an initiative of the Business Council of Australia - the majority of universities felt the influence of local industries was negligible in terms of having an impact on their curriculum. Efforts to increase interaction with external partners are, however, under way and, in some cases, are being promoted by top university officials. In the case of Victoria University, it is the vice-chancellor who is spearheading these initiatives. Victoria University was one of the earliest universities to link the program to systems in the market. The Faculty of Business and Law and SAP signed an agreement in March 1998 to enable the university to develop courses and conduct research based on SAP's Enterprise Resource Planning System, referred to as SAP R/3. In the case of Monash, the Dean of Information Systems and full professors were primarily instrumental in this area. At Swinburne, the faculty as a whole was attempting to increase ties to industry to be 'alert to any possible "competitive advantage" in responding to special local needs'. Where local influences were present, the most influential industries named were manufacturing and consulting services. At the ACU National, IS curricula are not affected by local factors but are affected more by the ethical influence in the Catholic mission as well as ethical and social responsibilities, which will influence the curricula to a certain extent.

National influences, on the other hand, are affecting IS curricula across Victoria. For example, Monash appears to be affected more strongly by national rather than local community and industry influences, or by individual influences within the university attributed to staffing changes over the years. Likewise, Swinburne 
saw national influences as being most influential. Overall, these findings suggest that IS programs in Victorian universities have achieved a certain degree of professionalism.

\section{Review of findings}

Despite declining enrolments and dwindling research support, from a teaching perspective, IS programs in the universities in Victoria appear to be well placed to provide top-calibre IS graduates at the undergraduate and postgraduate levels to meet the projected increased demand from industry and IS programs projected for the next five years. Programs at all tertiary education levels are varied and carefully crafted, influenced by national rather than local impacts.

It is encouraging to see that the research output and quality of the IS community in Victoria have improved greatly in the past few years. A large number of IS academics have gained PhDs, published in leading IS journals, joined editorial boards of prestigious journals and some have obtained ARC Linkage and Discovery grants. While research topics are diverse within the state, methods are not. Information systems academics in Victoria appear to align themselves more closely with interpretivist European research traditions than with the quantitative, positivist approaches found more commonly in North America. Despite the increased importance that research appears to have in measuring performance, funding is dwindling and success in securing external competitive grants such as those offered by the ARC appears to continue to elude the majority of IS researchers in Victoria.

It is encouraging to see that the Victorian government is acting to combat the declining number of IS students. For example, in 2005, Multimedia Victoria initiated a project - the Industry and Universities Collaboration Pilot Program - to encourage more students to enrol in IS courses in Victorian universities. The program provides funds to universities in Victoria to promote and improve IS courses and is designed to benefit all universities in Victoria.

In addition, Marsha Thomson, the state Minister for Information, Communication and Technology, convened a meeting on 26 May 2006 to discuss matters relating to an apparent shortage of ICT skills in Australia, and notably in Victoria.

The cyclical nature of demand for IS courses was seen, in most cases, to be the factor that influenced IS enrolment most. Some respondents emphasised it was not always factors 'local' to their Australian location that affected their IS curriculum. For example, RMIT's IS program was impacted on by factors at its offshore Hong Kong location. This is not surprising since many of the universities indicated that international students accounted for a large percentage of their enrolments at graduate and postgraduate levels.

In conclusion, IS programs in Victoria appear to be evolving to meet the demands of industry from a teaching perspective, but are somewhat lacking in the area 
of research output vis-à-vis their counterparts in other departments. While some universities have, however, yet to establish IS as a separate entity, research output is increasing along with efforts to win external competitive grants. It would appear that the main challenges being faced include the significant drop in students studying IS and the expected drop in full-fee overseas students, coupled with the foreshadowed replacement of the Research Quality Framework (RQF), which will focus attention on the quality of IS research. Opportunities include building on recent successes in IS research in Victoria, which should lead to a stronger IS research base in the future.

Assessing the data along the dimensions of professionalisation and conditions for acceptance as an academic discipline indicate that while the IS discipline in Victoria has worked hard to achieve a certain degree of professionalisation, it has a long way to go before it can be considered a mature academic discipline.

\section{Limitations and future research}

The Victorian study draws on interview data from all nine Victorian universities, however, it does not represent all campuses or a majority of viewpoints within the IS departments. At some universities, only one point of view is represented and, at best, the data is compiled from only three viewpoints. Historical data were even more limited across all universities and this should be taken into account when considering the conclusions reached.

By the nature of the data-collection process, this research provides a snapshot in time of what would appear to be a rapidly changing environment. In particular, the recent increase in demand for IS/IT skills would suggest the need to take a longitudinal approach to data collection to replicate the study at set periods over time. This approach would reveal trends in teaching and research and track the maturation of the IS discipline in Victoria.

\section{General findings from the Victorian study}

Two main lessons were learned from conducting the Victorian study.

1. Interviews take time and scheduling is difficult. Given the large time commitment required for interviews and the difficulties associated with coordinating schedules to conduct an interview, it is envisioned that in future studies it might be more appropriate to use a survey approach and, with this in mind, a survey has been developed to replace the interview protocol used in this study. To improve the richness of the data collected via the survey, many open-ended questions are included.

2. A guiding theoretical framework is essential. The Ridley framework proved invaluable in developing the interview protocol (and subsequent survey) that enabled the researchers to focus their questions and assess their findings. Without it, it would have been impossible to conduct a valid 
comparison of the Victorian data with those of all other states in Australia. Given that other countries where this type of data-collection effort might prove useful have considerably more universities than Australia, it is anticipated that the Ridley framework will prove even more valuable in assisting researchers to collect, analyse and assess their findings.

\section{Acknowledgements}

The authors would like to express their gratitude to Angela Scollary for her valuable contribution to the data-collection phase of this research project.

\section{References}

ACM, AIS and AITP 1997, IS'97 Model Curriculum and Guidelines for Undergraduate Degree Programs in Information Systems, viewed 30 May 2006, <http://webfoot.csom.umn.edu/faculty/gdavis/curcomre.pdf>

Ang, A. Y. 1992, 'Australian information systems curricula: a comparison between the views of universities and TAFE colleges', Proceedings of Third Australian Conference on Information Systems, Wollongong, Australia, 5-8 October, pp. 747-58.

Ang, A. Y. and Lo, B. W. N. 1991, 'Changing emphasis in information systems curricula: an Australian industrial perception', Proceedings ACC'91 MOSAIC, Adelaide, 6-10 October, pp. 11-28.

Avison, D. E. 1993, 'Research in information systems development and the discipline of information systems', Proceedings of 4th Australasian Conference on Information Systems, Queensland, Australia, 1-27 September, pp. 28-30.

Benbasat, I. and Weber, R. 1996, 'Research commentary: rethinking "diversity" in information systems research', Information Systems Research, vol. 7, no. 4, pp. 389-99.

Boudreau, M., Gefen, D. and Straub, D. 2001, 'Validation in information systems research', MIS Quarterly, vol. 25, no. 1, pp. 1-16.

Buckingham, R. A., Hirschheim, R. A., Land, F. F. and Tully, C. J. 1987, 'Information systems curriculum: a basis for course design', in Buckingham et al. (eds), Information Systems Education: Recommendations and Implementation, Cambridge University Press, Cambridge, Great Britain, pp. 114-33.

Checkland, P. and Holwell, S. 1998, Information, Systems and Information Systems - Making Sense of the Field, University of Illinois Press, Urbana, Illinois.

Clarke, R. 1999, Comments on Information Systems Curriculum, viewed 26 March 2007, <http://www.anu.edu.au/people/Roger.Clarke/SOS/ISCurric.html> 
Denzin, N. K. and Lincoln, Y. S. 1998, The Landscape of Qualitative Research, Sage, Thousand Oaks, Calif.

DeSouza, K. C., El Sawy, O. A., Galliers, R. D., Loebbecke, C. and Watson, R. 2006, 'Beyond rigor and relevance towards responsibility and reverberation: information systems research that really matters', Communications of the AIS, vol. 17, pp. 341-53.

Dickson, G. W., Benbasat, I. and King, W. R. 1982, 'The MIS area: problems, challenges and opportunities', DataBase, vol. 14, no. 1, pp. 7-12.

Fielden, K. 1990, 'Facts, skills and creativity: an innovative approach to learning in information systems', Proceedings of First Annual Conference on Information Systems, Monash University, Melbourne, Australia, 6 February, pp. 2-14.

Government of Victoria 2005, Key Facts, viewed 26 March 2007, $<$ http://invest.vic.gov.au/Archive/Industry+Sectors/It+and+Communications/ Key+Facts.htm>

Government of Victoria 2006, Melbourne Home to New Headquarters for Leading Israeli IT Company, 27 April, viewed 26 March 2007,

$<$ http://invest.vic.gov.au/News/News+Archive/ness+technologies.htm>

Kanungo, S. 2004, 'On the emancipatory role of rural information systems', Information and People, vol. 17, no. 4, pp. 407-22.

Keen, C. 1996, 'A survey of course work Masters in information systems in Australia', in D. Arnott, K. Dampney and A. Scollary (eds), The Australian Debate on Information Systems Curriculum, Proceedings of the Australian Information Systems Curriculum Working Conference, Monash University, Australia, 24-25 September, pp. 119-32.

Lee, A. 2001, 'Editor's comments', MIS Quarterly, vol. 25, no. 1, pp. iii-vii.

Lo, B. W. N. 1989, 'A survey of information systems educational programmes in Australian tertiary institutions', Working Chapter Series No. 1, Department of Information Systems, The University of Wollongong.

Mingers, J. and Stowell, F. (eds) 1997, Information Systems: An Emerging Discipline?, Maidenhead, McGraw-Hill, Maidenhead, UK.

Newcomersnetwork.com 2006, Business in Melbourne, Victoria, Australia-Facts, figures, information, statistics, industries, manufacturing, biotechnology, ICT, innovation and more, viewed 26 March 2007, $<$ http://www.newcomersnetwork.com/mel/oursay/expertadvice/bimv.php>

Ridley, G. 2006, 'Characterising information systems in Australia: a theoretical framework', Australasian Journal of Information Systems, vol. 14, no. 1, pp. 141-62. 
Tatnall, A. 1999, Innovation and change in the information systems curriculum of an Australian university: a socio-technical perspective, $\mathrm{PhD}$ thesis, Central Queensland University.

Walsham, G. 1993, Interpreting Information Systems in Organization, Wiley, Chichester.

Walsham, G. 1995, 'Interpretive case studies in IS research: nature and method', European Journal of Information Systems, vol. 4, pp. 74-81.

Whitley, R. 1984a, 'The development of management studies as a fragmented adhocracy', Social Science Information, vol. 23, no. 4-5, pp. 775-818.

Whitley, R. 1984b, The Intellectual and Social Organization of the Sciences, Clarendon Press, Oxford, UK.

Wikipedia, The Free Encyclopedia 2007, Victoria (Australia), viewed 26 March $2007<$ http://en.wikipedia.org/wiki/Victoria_(Australia)>

Yin, R. K. 2003, Case Study Research: Design and Methods, 3rd edn, Sage, Thousand Oaks. 